Poznańskie Studia Teologiczne 27(2013), s. 107-115.

Bogusław Kochaniewicz

Uniwersytet im. Adama Mickiewicza w Poznaniu

Wydział Teologiczny

\title{
Cinematographic Transformations of the Gospel. A Mariological Perspective
}

\section{Introduction}

The present essay proposes a reading of two movies dedicated to the Mother of God: Marie de Nazareth, a 1994 French picture directed by Jean Delannoy, and Mary, Mother of Jesus, which was released five years later ${ }^{1}$ and directed by Kevin Connor.

These films are part of a series of movies about the Mother of God and were made in the $20^{\text {th }}$ century. One of the earliest is the Polish movie, Pod Twoja Obrone (1933), directed by Józef Lejtes and Edward Puchalski while one of the most controversial was Jean-Luc Godard's Je vous salue Marie (1984). ${ }^{2}$ Among these Marian movies, R.F. Esposito considered La porta del cielo (1944), directed by Vittorio de Sica, The Gospel of Saint Matthew (1964), a masterpiece of Pier Paolo Pasolini, and La Via Lattea (1969), directed by Luis Buñuel, to be the most important. They have different messages, such as the cinematic story of the miracle in the sanctuary of Jasna Góra in Częstochowa, the testimony of pilgrims regarding the role of Mary in their lives, the biography of the Mother of Jesus based on the Gospels, and the French films which intended to blaspheme.

Both of the movies which will be analyzed can be considered Marian biographies which generally remain faithful to the Gospel message. These films remind us that it is difficult to portray the life of the Virgin Mary in an accurate and interesting manner. While works of art, iconography, and sculpture perpetuate single events of her life, an audiovisual presentation attempts to reconstruct everyday life with details which are in large part unknown to the artist. ${ }^{3}$ Furthermore, while Marian images are static and designed for contemplation, cinematographic

\footnotetext{
${ }^{1}$ According to criteria of Marian movies presented by R.F. Esposito, both films belong to the category of intended for a wide audience feature-length pictures, which protagonist is Mother of God. Cfr. R.F. Esposito, Cinema, in: Nuovo Dizionario di Mariologia, ed. S. Meo, S. De Fiores, Cinisello Balsamo 1986, p. 369.

${ }^{2}$ Cf. R.F. Esposito, Cinema, op. cit., p. 370.

${ }^{3}$ Ibidem, p. 371.
} 
presentations include action and motion. ${ }^{4}$ This implies a lot of directing operations to meet the requirements of the image produced contemporary critics

\section{The main perspectives of the movies about the Mother of God}

Perspectives of these pictures put in evidence that they are deeply set in historical reality. The historical dimension allows for an emphasis on God's salvific plan which unfolds in the chronological events experienced by the chosen people. ${ }^{5}$ Such a perspective also allows directors both to accentuate the circumstances of everyday life in Israel and to bring into relief the political context of that period. It is for this reason that the movies portray the events described on the pages of the Gospel with gusto: the childhood, public ministry, passion, death, and resurrection of Jesus of Nazareth.

Although the titles of both movies seem to suggest that their main character will be Mary of Nazareth, in reality, the central figure of both films is Jesus, her son. Mary, his mother, appears at his side. The Marian dimension of the movies is also revealed by Mary's presence at those moments of Jesus' life which are not mentioned in the Gospel: Mary participates in her son's mission, listens to his teaching, receives John's baptism in the Jordan river like her son, is present in the Cenacle during the institution of the Eucharist, listens to her son's prayer in the garden of Gethsemane, accompanies him during the way of the cross, is present at Calvary, becomes a witness of his death, and meets Jesus risen from the dead.

Another characteristic of these two films is their emphasis on Christ's humanity. The movies underscore the reality of this world to the detriment of the divine and supernatural. This is clear from the scarcity of scenes in which Jesus reveals his divinity by working miracles in both films. ${ }^{6}$

\section{Ways of interpreting the Gospel}

Analyzing different Gospel's interpretations in the productions under discussion, the following aspects are highlighted. The Marian movies directed by Jean Delannoy and Kevin Connor present scenes which are not precisely reported in the Gospels and thus become the subject of theological reflection.

\footnotetext{
${ }^{4}$ Ibidem.

${ }^{5}$ It corresponds to the historic-salvific perspective which dominates Chapter 8 of the Dogmatic Constitution on the Church, "Lumen gentium," of the $2^{\text {nd }}$ Vatican Council.

${ }^{6}$ The perspective adopted by the directors of both films is different from the first Italian film in color, executed in 1950 and entitled "Mater Dei", directed by Emilio Cordero. Cfr. V. Giacci (a cura di), Mater Dei. Storia e rinascita del primo film italiano a colori, Roma 2005.
} 


\section{a. The presence of themes which are the subject of theological debate}

One of the topics that attracts the interest of theologians is the person of St. Joseph. The Gospels do not state, for instance, how old he was when he married Mary. Throughout the ages two images of Joseph evolved. The first and more popular one presents the spouse of the Blessed Virgin Mary as an old man, a widower, who married a young girl named Mary. The second version shows him as a young man who asks Joachim and Anna for Mary's hand. ${ }^{7}$ Both movies prefer the latter image of Joseph.

Another topic of theological reflection is the question of Mary's genealogy. Whereas the Gospels are unanimous in stating that Joseph came from David's family, the Blessed Virgin's ancestry is given rather vaguely. Kinship with Elizabeth might suggest that Mary came from the priestly family of Aaron, but there is also a hypothesis according to which Mary was related to the family of David. ${ }^{8}$ It is worth mentioning that both movies opt for the second possibility.

The next issue concerns the circumstances of Jesus' birth. Scripture does not answer the question whether Mary felt any pain when delivering Jesus into the world or was rather preserved from any suffering. Christian tradition provides two solutions to this problem. The first one argues that since pain at childbirth was a consequence of original sin, and Mary was free of that, Mary's childbirth proceeded painlessly. ${ }^{9}$ The second opinion, prevalent among contemporary Mariologists, represents a more realistic approach to the mystery and stresses the suffering of the mother when bringing her son into the world. ${ }^{10}$

Both solutions are present in the films mentioned: in Marie de Nazareth the Blessed Virgin delivers Jesus in the pains of childbirth, whereas in Kevin Connor's production Mary gives birth to Jesus without experiencing any pain.

The screenwriters also wrestled with the question whether Jesus carried a complete cross to Calvary or only the horizontal beam. The movies do not give an explicit answer. In Jean Delannoy's production Jesus carries the whole cross, but in Mary, the Mother of Jesus he carries only the beam.

Another theme which inspires theological reflection is the encounter between Mary and the risen Jesus. ${ }^{11}$ Despite the Gospel's silence on this topic, the Eastern

7 T. Stramare, Giuseppe, in: Nuovo Dizionario di Mariologia, ed. S. Meo, S. De Fiores, Cinisello Balsamo 1986, p. 634-645.

${ }^{8}$ R. Laurentin, I Vangeli dell'Infanzia di Cristo, Cinisello Balsamo 1986, p. 175.

${ }^{9}$ For example: Origen, St. Epiphanius of Salamine, St. Ephrem, St. Gregory of Nysse. Cf. G. Soll, Storia dei dogmi mariani, Roma 1981, p. 86-102.

${ }^{10}$ S. De Fiores, Vergine. Prospettive teologiche attuali, in: Nuovo Dizionario di Mariologia, ed. S. Meo, S. De Fiores, Cinisello Balsamo 1986, p. 1464-1469; R. Laurentin, Sens et historicité de la conception virginale, in: AA.VV. Studia mediaevalia et mariologia P. Carolo Balic OFM septuagesimum explenti annum dicata, Roma 1971, p. 515-542.

${ }^{11}$ This question is mentioned in the writings of the following Christian authors: St. Gregory of Nysse, St. John Chrysostom, Sever of Antioch, John of Thessalonica, St. Peter Chrysologus. Cf. B. Kochaniewicz, La Vergine Maria nei sermoni di san Pietro Crisologo, Roma 1998, p. 249-251. 
tradition has developed this theme. It also appears in the movie by Kevin Connor. The Servant of the Lord meets her son on the hill after he had emerged from the empty tomb which she came to visit with other women.

\section{b. Fictitious plot that complements the Gospel}

Neither film uses material contained in apocryphal literature in depicting the life of Jesus and Mary. Although in presenting the biographies of the main characters, both pictures basically rely on the Gospel accounts, quite a few fictitious subplots have been added to enrich the narrative. In the case of some of those additions, the probability of the situation occurring is very high, but in several other cases the invented events evoke a smile of forbearance or amazement on the countenance of the viewer.

An example of such a fictitious development is the scene of the Holy Family's flight into Egypt. According to the authors of Mary, Mother of Jesus, Joseph and Mary escape literally at the last moment from an inn surrounded by Herod's soldiers. The movie not only shows the hardships of Mary and Joseph's travel across the desert but also fixates on the hill where victims of persecutions launched by Herod are crucified.

While traveling across Egypt, Mary and Joseph stop at the statue of an Egyptian deity to offer up prayers to the One God. Kevin Connor's film supplies a detail that on arrival to Egypt, Mary and Joseph settled down in a Jewish colony thanks to the hospitality of Jacob of Emmaus, a Jew who had escaped from Palestine to avoid Herod's persecutions. This kind of approach is an attempt to fill in missing information about the period of the Holy Family's stay in this foreign land. Moreover, it furnishes the political context in which Jesus' parents had to live.

Regrettably, not all attempts to add to the plot are successful. For instance, the viewer of Mary, Mother of Jesus watches with astonishment and even embarrassment a scene in which little Jesus is beaten and bullied by his peers because his refusal to render evil for evil provokes them to vent their anger at him.

A certain dose of forbearance is included in thesscene at the wedding at Cana in Galilee (Jn 2:1-12) where according to Mary, Mother of Jesus, Jesus danced with his mother.

Whereas the Gospels provide reserved accounts of Mary's presence at the foot of Jesus' cross, both films focus on the drama that unfolds at Calvary and show the tragic presence of the mother of Jesus at Golgotha as she weeps, cries out, suffers from pain, and accuses the sleeping apostles of cowardice (Marie de Nazareth).

\section{c. Providing the particulars}

The movies discussed here make several attempts to provide details recorded on the pages of the Gospel. For example, according to Marie de Nazareth the 
baptism of Jesus and Mary took place at Beth-barah, while Simon Peter's profession of faith in Christ's divinity as well as entrusting to him the power of the keys occurred at Lake Tiberias at sunset.

\section{d. Fictitious dialogues which help to understand the Gospel}

The dialogues between the characters, even though they refer to scenes from the Gospel, do not occur as such in Scripture. However, they often help the viewer understand the meaning of the events narrated in the Gospels better.

For example, the scene from Mary, Mother of Jesus, in which Joseph discovers that his wife is expecting a child, offers the following dramatic dialogue:

Joseph: What happened?

Mary: Do you believe that nothing is impossible to God?

Joseph: I do.

Mary: An angel of the Lord came to me. This is a child of God.

Joseph: You are out of your mind.

Mary: I swear I was not with any man.

Joseph: You pledged and you were unfaithful.

Mary: No, I wasn't.

Joseph: Think how we should part. I cannot take you for my wife, not after what you have done. To me, you are dead.

This theme is also present in Marie de Nazareth. A short exchange between Joseph and Mary is no less dramatic in its expressiveness:

Joseph: I'm not asking about anything, neither his name, nor when? You know I have the right to have you put to death, stoned to death? Aren't you afraid?

Mary: No, I'm happy, but I'm also a little scared. Joseph, the child that I carry was not conceived in sin. You will find out when you are ready to accept this truth.

Sometimes the purpose in embellishing the Gospel narratives by means of made-up dialogues is to draw attention to issues which could escape the viewer's attention. One example of such a fictitious expansion of the plot is the scene when Jesus' brothers and mother come to talk to him, described in Mark's Gospel (Mk 3:31-35). Jesus' surprising answer about who is his mother and brothers is misunderstood and commented upon by the listeners as follows:

People: Jesus said, who is my mother and who are my brothers. He has no regard for his mother or his family. Poor Mary, your son has renounced you. He is slightly out of his mind, that's all (cf. Mk 3:21). We can't be of any help here.

Mary Magdalene: They are right, Mary. Sometimes he says strange things.

Mary: Yes, he has a strange way of speaking. Even I don't understand everything. When he speaks in parables I am puzzled. Those are the words of the Father, only we don't understand what says. 
Mary Magdalene: He has no regard for his family, so be it, but not even for you, his mother?

Some more of these dialogues serve the purpose of showing or describing a unique mother-son relation between Mary and Jesus. In Marie de Nazareth, after Jesus announces his passion, death, and resurrection, an interesting dialogue between him and his mother takes place:

Jesus: We are on our way to Jerusalem, there the Son of Man will be handed over to the high priests. They will condemn him to death and hand him over to the heathens to be mocked, scourged, and crucified. And on the third day he will rise from the dead. [...] What do you want, woman?

Mary: Must you go to Jerusalem?

Jesus: I must.

Mary: Why so soon?

Jesus: Because everything that the prophets wrote about must come to pass.

Mary: It was so short ago that you were a child and I led you by the hand to the synagogue.

Jesus: I will always be your child.

There is also a short dialogue between Judas and a priest when Judas informs the Pharisees of the place where Jesus is staying. This is not found in the Gospels:

Priest: Tell me, Judas, why are you betraying your Messiah?

Judas: Guess.

\section{e. Compilation of selected passages from the Gospel}

Both movies contain themes that are new and original. Some of the words spoken by characters from the Gospel have been put in the mouths of other figures and are uttered in different circumstances. An example can be found in Jean Delannoy's move when Jesus converses with Rabbi Samuel at the wedding at Cana in Galilee. The words of a rich young man and a Pharisee in the Gospel have likewise been placed here in the mouth of the Rabbi:

Rabbi Samuel: I, Rabbi, keep all the commandments. I pay tithes on mint and dill and caraway (cf. Lk 18:12).

Jesus: Samuel, if you want to be perfect, go, sell all that you own and distribute the money to the poor.

Samuel: The point is, that I own many possessions and have many children (cf. Lk 18:18-23).

Jesus: It is easier for a camel to pass through the eye of a needle than for a rich man to enter the kingdom of God (Lk 18:25).

The screenwriters frequently compiled passages from various discourses of Jesus. For instance, one of the discourses of the Saviour in Marie de Nazareth is 
a synthesis of different speeches by Jesus recorded in the Gospels of Matthew and Luke:

I am sending you out like sheep among wolves; so be cunning as serpents and yet as harmless as doves. Go and proclaim that the kingdom of heaven is close at hand. Cure the sick, raise the dead, cleanse the lepers, cast out devils. You received without charge, give without charge (Mt 10:16). I am not here to bring peace on earth but division. I come to divide the son against father, daughter against mother, daughter-inlaw against mother-in-law. From now on a household will be divided (Lk 12:51-53). He who loves his father or mother more than me is not worthy of me. He who does not take up his cross and does not follow me is not worthy of me. For anyone who wants to save his life will lose it; but anyone who loses his life for my sake will find it (Mt 16:24-25).

\section{Deformation of the Gospel message}

\section{a. Reduction of essential passages from the Gospel}

Both movies introduce abbreviations and reductions that impoverish the essential message of the Good News despite an abundance of means of expression at the disposal of the director to unfold the content of the Gospel. In Jean Delannoy's movie, the Lord's Prayer is reduced to the words: "Our Father in heaven, may your name be held holy, your kingdom come". Another example are Jesus' beatitudes which here are limited to only a few.

In Jean Delannoy's film, we also find a modification of Jesus' words. The Teacher of Nazareth was supposed to have addressed his disciples gathered on the banks of Lake Tiberias in the following words:

Jesus: Peter, James, Matthew, Thomas, Andrew and you Judas, come over here. Who do people think the Son of Man is? John the Baptist, Elijah, Jeremiah, Isaiah? And you, who do you think I am?

Simon Peter: You are the Messiah, the Son of the living God. ${ }^{12}$

\section{b. Behaviour of characters that is no mentioned in the Gospel}

Another example of a deformation of the Gospel narratives is the introduction of behavior unknown in the Gospels of persons known from the Gospels.

In Mary, Mother of Jesus the Blessed Virgin tells child Jesus as a bedtime story the parable of the good Samaritan, which in the Gospel Jesus tells in the

12 "«Who do people say the Son of Man?» And they said: «Some say John the Baptist, some Elijah, and others Jeremiah or one of the prophets. But you», he said, «who do you say I am?» Then Simon Peter spoke up and said: «You are the Christ, the Son of the living God»" (Mt 16,13-16). 
course of his public teaching (Lk 16:30-37). In the same movie, Mary standing at the foot of the cross prays the words of the Lord's Prayer. John's Gospel makes no mention of such an occurrence.

Another deformation can be noticed in the scene where the crucified Jesus entrusts Mary to his beloved disciple. Jesus mentions the name of this disciple: "John, this is your mother", which is absent in the Gospel (Jn 19:27). What is more, according to the Scripture John from that moment received Mary into his care (Jn 19:27), ${ }^{13}$ but according to Kevin Connor this happened only after Jesus rose from the dead.

\section{Conclusion}

The examination of two contemporary films about the life of Jesus and his mother shows similarities between them in their approaches to the biography of the Saviour. Both screenwriters endeavored to underscore the historical, social, political, and cultural dimensions of the times in which Jesus lived. It is in this perspective that they show Christ's salvific mission and the fullness of divine revelation that became present in him. It is only against this backdrop that the person of his mother is portrayed.

The wide range of cinematographic tactic used by the filmmakers allowed them to develop and underscore certain aspects when interpreting themes which occur or are absent in the New Testament. Viewed in this light, the two films on Marian topics analyzed here show the screenwriters' care to present the person of Jesus' mother in a faithful, true, and authentic way. The observed transformations serve the purpose of deepening certain aspects and bringing unknown themes to light so as to show the life of Jesus' mother in an attractive and genuine manner. They do not cause any significant deformation of Mary's image.

Does this mean the movies are free from imperfections? In my opinion, both films are too horizontal in spite of their respective efforts to depict the circumstances of the lives of Jesus and Mary faithfully. Even both films present Jesus and Mary in historical perspective, the supernatural dimension is virtually absent. Both films pay little attention to divine interventions and to the miracles worked by Jesus during his ministry, concentrating only on the crucial ones: the Incarnation, Divine Birth, and the Paschal Mystery. The point is not to make subsequent apocryphal stories in pictures that would abound in all sorts of manifestations of miraculous and supernatural phenomena, depriving the person of Jesus of reality in the process. What is at stake is the language of the message, a new vivid language that uses symbols which, on account of its unspecified character, would be

13 "«This is your mother». And from that hour the disciple took her into his home" (Jn 19,27). 
simultaneously mysterious but open to transcendence, allowing the viewer to aspire to transcendental values, to touch the inconceivable, the untouchable, and the holy.

As a theologian going to the movie theater, I hope that the new language which authors of new movies on religious topics use will enable a more comprehensive description of the mystery of the One who is Limitless and Indescribable.

\section{Filmowe transformacje Ewangelii. Perspektywa mariologiczna}

\section{Streszczenie}

Artykuł Filmowe transformacje Ewangelii. Perspektywa mariologiczna przedstawia analizę dwóch współczesnych obrazów o życiu Jezusa i Jego Matki: pochodzącego z roku 1995 francuskiego filmu Marie de Nazareth w reżyserii Jeana Dellanoya oraz powstałego cztery lata później dzieła Kevina Konnora Mary, Mother of Jesus. Przedmiotem analizy jest filmowa interpretacja życia Jezusa i Jego Matki opisanego na kartach Ewangelii. Charakteryzując obydwa obrazy, autor zauważył, że scenarzyści położyli akcent na wymiar historyczny, społeczny, polityczny i kulturowy epoki. W podobnej perspektywie ukazane zostało dzieło zbawcze Chrystusa oraz pełnia objawienia Bożego, która się w Nim zrealizowała.

Należy podkreślić, że reżyserzy obydwóch obrazów wykazali troskę o to, aby postać Matki Jezusa została przedstawiona w sposób jak najbardziej wierny, prawdziwy i autentyczny. Dostrzeżone transformacje ewangelicznych opisów miały na celu pogłębienie niektórych aspektów, wydobycie nieznanych wątków, aby w sposób atrakcyjny i autentyczny ukazać życie Maryi. Tego typu interpretacje nie doprowadziły do znaczącej deformacji obrazu Błogosławionej Dziewicy.

Dokonana analiza wykazała, że obrazy, mimo iż starają się wiernie oddać realia życia Jezusa i Maryi, to jednak akcentują zbytnio wymiar horyzontalny, podczas gdy nadprzyrodzony jest praktycznie nieobecny. Zbyt słabo podkreślono interwencje Boga w życiu Maryi oraz cuda dokonane podczas ziemskiej misji Jezusa, koncentrując się jedynie na najistotniejszych: wcieleniu, Bożym narodzeniu oraz tajemnicy paschalnej. Autor artykułu zauważa potrzebę stworzenia nowego języka, operującego symbolem, który byłby otwarty na wymiar transcendentny, pozwalając lepiej opisać tajemnicę Tego, który jest Nieogarniony i Święty.

\section{Słowa kluczowe}

Jezus, Maryja, Ewangelia, film, reżyser, interpretacja

\section{Keywords}

Jesus, Mary, Gospel, film, director, interpretation 